\title{
Legal, Reasonable And Fair Court Decision: Requirements, Analysis And Proposals
}

\section{Tazhiboev Marufjon}

Independent Applicant For The Higher School Of Judges Under The Higher Judicial Council Of The Republic Of Uzbekistan, Tashkent, Uzbekistan

G OPEN ACCESS
The American Journal of
Social Science and
Education Innovations
JUNE 2020
Page No. : $44-50$
Volume-II Issue-VI
PUBLISHED: 29 JUNE 2020
www.usajournalshub.com/in
dex.php/tajssei
Copyright: Original content
from this work may be used
under the terms of the
CreativeCommons
Attribution 4.0 licence.

\section{Abstract:}

The article discusses the issues of established requirements regarding the legality, validity and fairness of civil court decisions. Currently, issues related to the implementation of the principle of justice in the judicial sphere play a key role. It is not a secret for anyone that the well-known principle of justice is fixed at the legislative level, however, the presence of judicial errors is a fairly frequent occurrence in law enforcement practice. In the article, the aforementioned principle of justice and its manifestations in the sphere of the implementation of court decisions are analyzed. This issue clarifies and forms the need to use the principle of justice in making an objective and reasonable court decision. In addition, theoretical reasons and conditions of unfair court decisions are described in detail, and constructive mechanisms to combat judicial errors are highlighted. As a result of the study, it was concluded that the illegality and injustice of the court decision directly depends on both external and internal (psychological) factors.

Keywords: civil case, court decision, legality, validity, justice, review of judicial acts.

\section{Introduction:}

Many civil cases are resolved in civil courts in order to protect rights and legitimate interests of citizens and organizations in civil proceedings. Meanwhile, opinions and conclusions of the court in civil cases and disputes are expressed in the form of court 
decisions issued in a certain procedural form .[1]

Thus, the court decision is an important document of justice aimed at protecting the rights and legitimate interests of the parties to the conflict. As noted in the legal literature, the substance of the decision is influenced by its material-legal relations, and they strictly confirm to the relationship between legal relations between the entities (regardless of whether there has been a change in relationship) or other equal aspects of the case without prejudice and to protect interests in accordance with the law without any obstacles. In this sense, a court decision is a very important document of justice that essentially resolves the case. [2]

Simultaneously, court decision is an important document of justice that imposes on judges special responsibility and attention when issuing it. The current legislation of our country also states that the decision in each case must be lawful and justified (Art. 176 EPC).

The analysis shows that some decisions made by courts do not meet the requirement that they be lawful, reasonable and fair. Some decisions do not fully reflect the facts of the case, do not analyze evidence, do not meet important tasks related to the assessment and legal interpretation of facts, and the court's findings on the dispute are not always true. Cases of inappropriate application of substantive law still can be come across. A number of court decisions do not cover the circumstances established by the court and do not include the findings of the court that create difficulties in their implementation .

In order to avoid the above disadvantages, and to ensure uniform application of the Code of Civil Procedure of the Republic of Uzbekistan (hereinafter referred to as CPC) court decisions must fully comply with its requirements and be legally justified and fair.

Part 3 of Article 18 of the CPC of the Republic of Uzbekistan, adopted on August, 30, 1997 and applicable until April,1 2018, contained a special provision that the court rulings, decisions, determinations must be lawful, reasonable and fair .[3] However, the new CPC of Republic of Uzbekistan, which came into force on 1 April 2018, contains no special provision, which states that rulings, decisions, determinations of the court should be lawful, reasonable and fair . [4]

The analysis shows that the decision is legal only if the rules of procedural law are strictly obeyed and the substantive law rules that must be applied to these legal relations are fully followed.

In paragraph 3 of the Decision of the Plenum of the Supreme Court of the Republic of Uzbekistan dated May 24, 2019 "On the decision of the court", it is explained that the decision is legal only if it is based on the principle of analogy of law, if it is adopted strictly in accordance with the rules of procedural law and in compliance with substantive law applicable to these relationships.[5]

The court decides whether or not to apply substantive law, regardless of the circumstances that are required in the case, but in any case it interprets the content of the 
rule of law and applies it to the circumstances of the case. At all stages of the civil process, the procedural rules must be strictly observed, which are the basis for the annulment of the decision (Article 377 of the CPC), in case of violation or incorrect application of the rules of law.

When applying substantive or procedural law, the court relies on the Constitution, laws, other regulatory legal acts of the Republic of Uzbekistan. Article 15 of the Constitution of the Republic of Uzbekistan declares the unconditional recognition of the supremacy of the Constitution of the Republic of Uzbekistan in the Republic of Uzbekistan. At the same time, Article 7 of the Law of the Republic of Uzbekistan, "On normative legal acts" dated December 12, 2012 establishes the supremacy of the Constitution and laws Republic of Uzbekistan. The Constitution of the Republic of Uzbekistan has the highest legal force and is valid throughout the territory of the Republic of Uzbekistan. Laws and other legal acts of the Republic of Uzbekistan are adopted on the basis and in accordance with the Constitution of the Republic of Uzbekistan and should not contradict its norms and principles. [6]

Any provisions affecting human rights and freedoms cannot be applied if they have not been officially published. Thus, the court must resolve cases on the basis of the Constitution and laws of the Republic of Uzbekistan. The court also applies other legislative acts, if this does not contradict the Constitution and laws of the Republic of Uzbekistan. In case of absence of rules governing disputes, the court applies the same rules of law governing such relations, and if such rules are also absent, a conflict is resolved on the basis of general principles and the content of laws. The court also applies the law of a foreign state in accordance with the legislation or an international treaty of the Republic of Uzbekistan (Article 14 of the CPC).

Indeed, legitimacy of the decision means that the courts adhere to generally accepted principles, norms and international treaties of the country. Therefore, if an international treaty of the Republic of Uzbekistan stipulates other rules than those provided for by the legislation of the Republic of Uzbekistan on civil proceedings, the rules of the international treaty (Part 3 of Article 1 of CPC ).

This primarily applies to international treaties and agreements: the Universal Declaration of Human Rights, adopted by the UN on December 10, 1948, European Convention for the Protection of Human Rights and Fundamental Freedoms, adopted on November 4, 1950, at the UN General Assembly on December 1, 1966 , the International Covenant on civil and political rights and the International Covenant on Economic, Social and Cultural Rights and other human rights enshrined in other treaties .

The next decision requirement is its validity. It is established that the court decision is based only on materials examined during the trial.

It should be noted that the decision is valid only when all circumstances having legal significance for the case are stated, the relevant facts are established and the correct conclusions are drawn in the case, as well as on the rights and obligations of the parties. 
Paragraph 4 of the Resolution of the Plenum of the Supreme Court of the Republic of Uzbekistan dated May 24, 2019 "On the decision of the court" stipulates that the court decision, facts relevant to the case are supported by evidence examined by the court, their relevance and admissibility comply with the law or there is no need for evidence concern for court, when the final conclusions are reflected, it is considered to be reasonable. [7]

The validity of the decision is directly related to its legality. If the initial requirement of a court decision is legality, i.e. is the legal side of the decision, validity is its actual basis. [8]

Consequently, the court's conclusion on the actual circumstances of the case is based on the evidence specified in the decision. The decision must be substantiated with due regard to the integrity of evidence and the admissibility of evidence.

Evidence refers to the facts that make up the subject of evidence, which ultimately determine the application of the relevant substantive law. If facts of legal significance are not established in the case, the decision is invalid and is canceled by a higher court. Consequently, the facts of the decision must be presented in the court decision. Failure to prove the facts confirms that the decision was not substantiated.

The next requirement for a court decision is justice, there is no such provision in the CPC of our country, as well as in the decision of the Plenum of the Supreme Court of the Republic of Uzbekistan dated May 24, 2019 "On court decision". Nonetheless, the new Code of Civil Procedure has a separate article 373, entitled "The right to appeal on the verification of the legality, validity and fairness of the judicial act" which states that persons defending own rights and responsibilities and involved in the case, as well as persons who have not been involved in the case, have the right to file a complaint (statement) on the verification of the legality, validity and fairness of the judicial act in the manner prescribed by law. The new CPC term "verifying the validity of the judgment" was used eight times, also, it is reflected in the provisions of Title IV of CPC "The revision of judicial acts". This necessitates the presence in our legislation of standards defining the criteria of justice and impartiality of court documents, or an explanation of the decision of the Plenum of the Supreme Court of the Republic of Uzbekistan dated May 24, 2019 No. 12.

As noted above, section 18 of the CPC contains a specific provision that court rulings, decisions and determinations must be lawful, justified and fair. New CPC of the Republic of Uzbekistan, which entered into force on 1 April 2018, removed a separate provision stating that the court determinations, regulations, decisions must be lawful, reasonable and fair.

Most studies in foreign countries confirm that civil procedural law establishes requirements for court decisions to be lawful and substantiated. For example, Article 195 of CPC of the Russian Federation is entitled as "Legality and validity of a court decision" and establishes that court decisions must be lawful and substantiated, court decisions are based only on materials considered at the hearing.[10] The same rule exists in the Code of Civil Procedure of the Republic of Kazakhstan, Article 224,[11] Article 297 of the Code of Civil 
Procedure of the Republic of Belarus[12], also Article 263 of the Code of Civil Procedure of Ukraine[13].

Thus, in our opinion, it would advisable to introduce a new standard that assures legality, reasonability and fairness of court decisions in the new CPC Republic of Uzbekistan (acting from April 1, 2018).

According to the new Civil Procedure Code of the Republic of Uzbekistan, a court decision consists of introductory, descriptive, motivating and resolving parts (Article 253 of the Civil Procedure Code).

Each part of the document has its own text and content, and together they form a court decision. In this regard, courts are liable to follow the sequence when writing the decision.[14]

The descriptive part of the decision must contain information about the date and place of the decision, the name of the court, name of the judge, court clerk, parties, third parties to the case, the plaintiff's claims, the defendant's objections and the explanations of other persons involved in the case.

The reasoning part of the decision shall indicate the circumstances of the case that guided the court, in particular, established by the court, evidence on which the court's conclusions about the circumstances of the case are based, as well as conclusions.

The resolutive part of the decision must contain the full name of the parties, the satisfaction of the claims (in whole or in part) or the conclusions of the court. It is also necessary to indicate the procedure for the distribution of legal expenses, the period and procedure for appealing the decision. Decision should be brief and concise in order to avoid causing misunderstandings and disputes in the implementation of them.

It should be noted here that in most cases, a record in the final part of the decisions of the issuance of a writ of execution after the decision has entered into legal force of is not very usual in judicial practice. Even in the literature on court decisions, model court decisions do not contain executive orders.

However, the Civil Procedure Code of our country requires the issuance of a writ of execution for judicial decisions, and this should be recorded in the decision. The fact that the resolutive part of decisions does not contain the procedure for issuing a writ of execution after the decision has entered into force does not in any way prevent the issuance of a writ of execution, but this can cause a number of misunderstandings.

Paragraph 25 of the Resolution of the Plenum of the Supreme Court of the Republic of Uzbekistan dated 24 May 2019 "On the decision of the court" in cases where the decision is subject to immediate execution according to the law (Article 266 CPC) or to allow immediate execution of the decision of the court (Art. 267 CPC) and is presented in the motivational and resolutive parts of the decision. [15]

In our view, both the person who supports the decision, and the person in regard to 
whom decision was imposed should know about the time of the issuance of a writ of execution and, secondly, it is important for the referee or his assistant as it helps to control time of issuance. Thirdly, after the entry into force of the decision, interested persons will be prohibited to re-apply to the court to issue a writ of execution. Most importantly, it increases people's confidence in the judicial system, improves the judicial system as well as legal awareness and legal culture of our citizens. Therefore, these problems will be solved by including the record "to issue a writ of execution after the entry into force of this decision" into the resolutive part of the decision.

\section{Reference}

1. Shorakhmetov Sh.Sh. Civil procedural law of the Republic of Uzbekistan. Tashkent: Adolat. 2001. $-231 \mathrm{pp}$.

2. Mamasiddikov M.M. Civil Court Judgments / Study Guide. -T.: Military Technical Institute of the National Guard, 2018. -4 pp.

3. Civil Procedure Code of the Republic of Uzbekistan // http://lex.uz/docs/186105 . This Code has expired on April 1, 2018 in connection with the Law of the Republic of Uzbekistan dated August 30, 1997 No. 477-I "On Approving the Civil Procedure Code of the Republic of Uzbekistan" in accordance with the Law of the Republic of Uzbekistan dated January 29, 2018 No. ZRU-463 "On amendments and additions as well as recognition as invalid of some legislative acts of the Republic of Uzbekistan".

4. Civil Procedure Code of the Republic of Uzbekistan // lex.uz/docs/3517337\#3523544

5. Decision of the Plenum of the Supreme Court "On the decision of the court" No. 12 of May 24, 2019 // http://lex.uz/docs/4396483\#4396539

6. The Law of the Republic of Uzbekistan "On regulatory legal acts" in the new edition of December 12, 2012 // http://lex.uz/docs/2105724

7. Decision of the Plenum of the Supreme Court "On the decision of the court" No. 12 of May 24, 2019 // http://lex.uz/docs/4396483\#4396539

8. Mamasiddikov M.M. Appealing Civil Court Judgments / Study Guide. -T.: Military Technical Institute of the National Guard, 2018. - 13 pp.

9. Economic Procedural Code of the Republic of Uzbekistan // http://lex.uz/docs/3523891\#3531087

10. Civil Procedure Code of the Russian Federation dated November 14, $2002 \mathrm{~N} 138$ FZ (as amended on July 26, 2019) www.consultant.ru

11. The Code of Civil Procedure of the Republic of Kazakhstan (as amended on July 22, 2019) http://online.zakon.kz 
12. Civil Procedure Code of the Republic of Belarus. http://pravokulichki.com/vip/gpk/index.htm

13. Civil Procedure Code of Ukraine // kodeksy.com.ua

14. Civil procedural law. Special part / Textbook. Group of authors: M.M.Mamasiddikov and others. Managing Editor DSc, prof. M.Kh. Rustambaev. -Tashkent. "VTI" publishing house. 2018. $-131 \mathrm{pp}$.

15. Decision of the Plenum of the Supreme Court "On the decision of the court" No. 12 of May 24, 2019 // http://lex.uz/docs/4396483\#4396539 